\title{
Heirs of Ambivalence: The Study of the Identity Crisis of the Second-Generation Indian Americans in Jhumpa Lahiri's Interpreter of Maladies
}

Hossein Aliakbari Harehdasht*, Muhammad Ataee, Leila Hajjari

Department of English Language and Literature, Persian Gulf University, Iran

Corresponding Author: Hossein Aliakbari Harehdasht, E-mail: aliakbari2007@gmail.com

\section{ARTICLE INFO}

\section{Article history}

Received: December 05, 2017

Accepted: January 17, 2018

Published: March 01, 2018

Volume: 7 Issue: 2

Advance access: February 2018

Conflicts of interest: None

Funding: None

\begin{abstract}
Jhumpa Lahiri's Interpreter of Maladies is a collection of short stories which, for the most part, deals with the identity crisis of the Indian Americans who are trapped in-between their Indian heritage and the American culture. The crisis is manifest in their unremitting struggle to preserve, to integrate, and to adjust. The collection, due to its dealing with the in-between-ness, ambivalence, hybridity, and marginality of the displaced Indian Americans, is receptive to the postcolonial studies. This essay draws on the relevant ideas and concepts in the field of the diaspora identity to examine Lahiri's "A Temporary Matter," "When Mr. Pirzada Came to Dine," "Sexy," and "This Blessed House" which portray identity crisis of the second-generation Bengali migrants. The ultimate objective is to investigate into the nature of the internal ambivalence of Lahiri's second-generation characters caused by the reciprocal influence of Host/Guest relationships. The significance of the present study is twofold; on the one hand, it accentuates the intellectual attention to the crisis of identity felt by the exponentially increasing second-generation diaspora; on the other hand, it attempts to attract concentrated scholarly interest in diaspora ambivalence which is one of Lahiri scholars' less addressed concerns.
\end{abstract}

Key words: Lahiri, Interpreter of Maladies, Diaspora, Identity, Ambivalence

\section{INTRODUCTION}

We live at a time when people around the world are urged by many varied forces to leave their homeland to start a living in a new region leaving most of their belongings behind; what does not remain in the mother land and immigrates along with them to the new land is the sense of belongingness to home which is attached to the soul of every migrant individual, a sense that is instigated mostly by the nostalgic memories of the people and places who/that address those memories and intensify the desire for home, hence occupational, political or cultural issues, ethnic conflicts, sheer boredom, etc. These are some of the main problems that they have to tackle with every day, which explains why so many people can easily connect and empathize with the victims of the diaspora and the associated tribulations materialized in their life.

Jhumpa Lahiri is one among many talented writers who, herself being subject to the displacement and to the internal tension for belongingness, has been able to dramatize the ups and downs of living a life in oscillation. The depth and honesty which are seen in Lahiri's demonstration of the characters' permanent tension and struggle is unique and originates from her own experience as a diaspora writer; she belongs with the second-generation Indian emigrants; she admits that she writes "from the perspective of someone, not technically born [in America, yet born in the West], but who might as well have been born and brought up in this country [America], with a different sort of division than [her] parents and that previous generation" (Leyda, 2011, p. 73). However, she mixes the reality of life with magical power of art in order to make visible all the fear and trembling of disjointed existence as a diaspora author. Hence, in an era when a host of various forces has pushed people out of orbit into disarray of displacement, her genuine and understanding perspective wins the confidence of her readers, both indigenous and foreign.

The readers are attracted to Lahiri's Bengali migrant personages' world seeing them commute both emotionally and mentally between two worlds that correspond with home and its other (the foreign country), and her Pulitzer-winning collection of short stories entitled Interpreter of Maladies beautifully and with meticulous observation of the details narrates that commute. In other words, it portrays the life of those who have to make a balance between two poles of existence, the original habitat and the new one. The duality that leads to both internal and external conflicts is unsurmountable in most cases. Nonetheless, the generations that she depicts are not always the first generation of the migrants who have had the experience of living in both mother land and the foreign one; her characters also include those who are born in the country that is foreign to their parents and indigenous 
to them. However, there are many reasons to claim that they are also subjected to a deep sense of displacement and loss of identity; they are at the center of ambivalence that corresponds with their attachment to both mother land and its other, hence the ambivalent (m)other land. Lahiri's second-generation characters' reactions towards the baffling and emotionally lush social atmosphere of immigration in the form of ambivalent acceptance and rejection of their own familial and cultural background matched against their socalled native country unmask the truth about the difficulties that they face in finding ways to endure the permanent condition of hybrid in-between-ness when finding resolution to settle down the heart-felt duality becomes hard to reach if not impossible.

The present research, therefore, attempts to uncover the ambivalence of Lahiri's second-generation migrant characters who are invariably subject to hybridizing forces of the American culture as well as their attempts, either failed or successful, to transform, to adjust to the novelty, to settle on the middle ground, or to hold on to their own cultural values and identities. Exploiting the relevant short stories that mainly address the second-generation migrants, "A Temporary Matter," "When Mr. Pirzada Came to Dine," "Sexy," and "This Blessed House," there will be an attempt in the up-coming pages to give exclusive attention to the inherited confusion of these migrants as heirs of diasporic ambivalence. It is hoped that the results of this study will be useful to those who want to further this or any other similar study of the issue of ambivalence in the second-generation migrants in Lahiri's stories which so far has been rarely addressed separately by Lahiri scholars.

\section{THEORETICAL/IDEOLOGICAL BACKGROUND}

Most of the studies on Lahiri's stories focus on the diasporic identity and on all the relevant ethnic, gendered, racial, or cultural aspects of it in the people who are homogeneously dubbed as diaspora. For example, Ketu H. Katrak (2002) has summarized Lahiri's stories as follows, which for the significance of every detail, we have to bring a full quote:

Lahiri's stories capture the humanity of ordinary people, struggling with "traditions," arranged marriage, food preparation, helping the destitute, people who take diasporic [emphasis added] leaps to create new lives even as they keep hold on the small details of their culture-eating with fingers, enjoying a specific regional pickle, speaking native languages, being dutiful. While Lahiri's characters remain self-consciously aware of their ethnicity, they participate in this US culture through their intimate relationships, married, single, raising children, driving that extra mile to get an absolutely necessary ingredient for a favorite recipe. Even as their ethnicity as South Asian Americans is performed in daily life, they work towards a hybrid realization of their subjectivity as Asians and as Americans. (p.6)

As we learn from the quotation, there is a general tendency among the critics to relate her stories to the common ethnic and cultural codes shared by all the characters of her stories. Most of the similar studies of Lahiri's stories show a tendency for the analysis of the ethnic, racial, or cultural issues shared by all the characters homogeneously, no matter whether they belong to the first or second generation, i.e. Indian-born or American-born. Basudeb and Angana Chakrabarti, in their investigations pertaining to the themes of Lahiri's stories, state that "this sense of belonging to a particular place and culture and, yet, at the same time, being an outsider to another, creates a tension in the individuals which happens to be a distinguishing feature of Lahiri's characters" (as cited in Brada-Williams, 2004, p. 4). Although Lahiri's main objective is, as Silvia Lutzoni (2017) observes, the depiction of "the thread of human relationships, [as well as] the lack of communication between people in a new context where they experience the same sense of loss," her aesthetic endeavor is lush with her concern with the displacement of those with whom she shares origins (p.111). She maintains that Lahiri does not attempt to communicate moral or political messages, neither does she attempt to deal with gender roles as feminism demands it; yet, her "Characters are depicted in a thick mist of human displacement, nostalgia and identity loss" (p. 111). Zygmunt Bauman asserts that identity is a "liquid concept," that is, "identity lacks its solid points of reference and needs continuous renegotiations across languages, cultures and geographies" (as cited in Lutzoni, 2017, pp. 111-112). Ruediger Heinze (2007), in his essay on The Namesake, confirms that the identity of the characters therein perpetually slips through their fingers, and this further complicates the "simplistic but conventional opposition between invention and authenticity" of identity (pp. 194-195). Gogol, Namesake's protagonist who is born into diaspora, finds both his "personal identity" and his "cultural identity" obscure (Heinze, 2007, p. 196). This struggle, however, has several levels of magnitude varying from one character to another.

These and other similar studies being quite illuminating furnish the needed grounds for the further penetration into the deeper layers of characterization in Lahiri's stories because the characters are not homogeneous, and the issues dealt by the different groups of the immigrants and by different generations are quite varied and complicated. As Lisa Lowe avers,

As with other immigrant groups in the United States, the Asian-origin collectivity is unstable and changeable, with its cohesion complicated by intergenerationality [italics added], by various degrees of identification with and relation to a "homeland," and by different extents of assimilation to and distinction from "majority culture" in the United States. (as cited in Deborah L. Madsen, 2003, pp. 94-95)

Bahmanpour (2010) states that Lahiri celebrates juxtaposing the discordant features of in-the-making identities in the batter of mixing cultures represented in "The Blessed House." As diaspora, "these two characters exhibit cultural identities in a state of fluidity and constant transformation" and represent 'the disconnection between first and second generation immigrants in the United States"' (p. 47). The study of hybridity must therefore be oriented towards a separate analysis of each group and of every generation not 
only for investigating the nature of the cultural gap between them but also for better apprehension of the vast versatility of hybridity.

Hybridity, however, has been addressed in various ways with regard to the migrants in general. What has always been disregarded is the fact that it is, more often than not, associated with profoundly negative assumptions. David Theo Goldberg (2005) has best captured the essence of the treatment that hybrids have received since the conception of the term far before it became popular in the postcolonial theory:

Hybridity is "a scandal," as Anne McClintock puts it provocatively (1995: 299ff), precisely because in the face of claims to the virtues of racial purity, of racial apartness and the imperative of racialized divides, it is deemed inherently, automatically transgressive. Perhaps once culturally and politically to be shunned, it is now in some circles fashionably (Colker, 1996), avant-gardedly (Bhabha, 1993) embraced. (p. 72)

Goldberg (2005) maintains that, the virtues associated with "monoculturalism" makes inevitable the virtue of "cultural - ethnoracial - homogeneity" (p. 73); nonetheless, immigration has been threatening the sanctity of this much celebrated cultural pride "at the expense of cultural and political repression" (p. 73). "Heterogeneity," as opposed to homogeneity, cannot be achieved without "exclusive and exclusionary" cultural similitude albeit the course of history proves its natural and inevitable development (p. 73). In almost all cultures, happiness is closely associated with variety, but societies paradoxically institutionalize their attempts toward shunning the other instead of cherishing the gift of diversity for human liberation and happiness. Therefore, for many, hybridity is paralyzing.

There is also another side to the problem of homogeneity vs. heterogeneity as some of the migrant people desire to get new identities in their new home instead of transforming the ones they already have. Ketu H. Katrak (2002) has an interesting remark on Bharati Mukherjee, another American Indian writer, 'Mukherjee embraces being 'American', not Indian and American, not hyphenated. What matters to her is that she wants to be recognized as 'an American writer' in the tradition of the American writers" (p. 5). In Mukherjee's own words, "The price the immigrant willingly [emphasis added] pays, and that the exile avoids, is the trauma of self-transformation" (as cited in Katrak, 2002, p. 5). Mukherjee as well as most migrant Indians have inclination towards the new identities rather than the trauma of transforming the one they already own. The desire to un-self oneself from the older identity to acquire a totally and purely new one is another challenging aspect of being a hybrid. This can best be examined in the second-generation diaspora who have less tight bondage with their ancestral culture.

Lahiri belongs to the second generation migrants, which is why, according to Hiral Macwan (2014), resourcefully captures the "bitter-sweet experience" of Indian diaspora from the perspective of the characters who share her experience, who are more often than not trapped in an "indeterminate state" where the "quest for identity never seems to end" (p. 47). She belongs very well with the authors who concern themselves with the instability and changeability. Her representation of America and the second-generation Asian Americans invites aesthetic and socio-cultural attention to this specific community.

The ambivalence that pains the second generation SouthAsians, and in Lahiri's case, Indian, Pakistani, or Bengali, minorities, has its roots within and without the displaced community. Delphine Munos, in her book which deals mostly with The Namesake, says that the hyphenated identity of these children and the manifested crisis demonstrate the "grief and guilt" which they have inherited from their parents. With her term, "entangled genealogies," she asserts that "the buried narratives of the parental generation, embedded in the fates and psyches of their offspring, produce a second generation that is 'always already buckling under profound feelings of inadequacy and guilt" (as cited in Anwer, 2017, p. 196). The devastation of these children is fueled by constant "rooting, uprooting and re-rooting,"

Longing for and belonging to a different homeland creates a void which cannot be filled . . . . It is like leaving the inherited for adopting temporary, notorious, glamorous future. The homeland is a pious place of worship in the Diaspora imagination. Nostalgia for homeland, feeling of rootlessness, instability, insecurity and isolation cause intense pain and grief, as reclaiming the past is impossible. Bicultural life entraps the immigrants in a dilemma. The couples are unable to acclimatize completely into the foreign culture and society. The intermingling of the eastern and western ethics irks lives .... Adopting the tradition of the native land and trying to learn new culture is a challenge. (Shukla and Banerji, 2012, p. 20)

According to Noelle Brada-Williams (2004), the "refusal of definite closure" is characteristic of many of Lahiri's short stories (p. 462). This is indicative of the fact that closure cannot be reached when dealing with an issue as fluid and perpetually mutating as identity among the displaced, hence a tour of Lahiri's second-generation-migrant-based stories of Interpreter of Maladies.

\section{ANALYSIS}

\section{A Permanent Matter}

In "A Temporary Matter," the first story in the collection, Shoba, a financially independent Indian woman, parts ways with her husband out of a marriage that has been going downhill after the death of their young child. The catalyst that contributes to and accelerates the departure is a forced blackout for eight succeeding nights; hence, a temporary matter of the title of the story. Since they, as Lahiri (1999) puts it, have "become experts at avoiding each other in their three-bedroom house," the blackout provides the right circumstances for Shoba and Shukumar to unmask their faces and start conversing and confessing their deepest fears and thoughts in the dark (p. 4). The characters' revelations, however, do not lead to a happy ending for the marriage.

Both Shoba and Shukumar, having been born in the US, are well cognizant of the fact that the new land, America, has 
given them the opportunity to explore their identities, hoping to mold the self that each one desires. As regards Shoba, her ambivalence is further reinforced by her mother and trips to India. Her mother always cooks Indian food, sets up a small shrine in the house, and respects the patriarchal authority of Indian culture. Shukumar's father's death triggers his yearning and search for his Indian story:

It wasn't until after his father died, in his last year of college, that the country began to interest him, and he studied its history from course books as if it were any other subject. He wished now that he had his own childhood story of India. (p. 12)

Srikanth (2003) notes that, due to "ethnic studies and multiculturalism movements" in the US, Asian academics born in America were "encouraged to find their ethnic and racial "roots"” (p. 96). Therefore, trips home and investigations into ancestral heritage were prompted. But, Edward Said, addressing the identity crisis, argues that "Identity who we are, where we come from, what we are - is difficult to maintain in exile ... we are the 'other,' an opposite, a flaw in the geometry of resettlement, an exodus. Silence and discretion veil the hurt, slow the body searches, soothe the sting of loss" (as cited in Ashcroft and Ahluwalia, 2001, p. 3). Therefore, what aggravates the pains of exile is that migrant people usually tend to be taciturn in order to save face in the eyes of other migrants, and to demonstrate their appreciation for the opportunities offered by the new community. Thus, silence hinders the process of identity realization and formation and, consequently, furthers the gap between their fellow immigrants and the indigenous ones.

Second generation diaspora, being born into the host culture, might have easier time being assimilated into the host society; nevertheless, they are still the other. Hiral Macwan (2014) claims that "Increasing acceptance into the host society does not indicate that the Diaspora characters can feel at home" (p. 46). When the couple awaiting the liberating darkness are asked by their American silver-haired neighbors to join them for a browsing walk, they simultaneously turn down the invitation. This refusal and the serial confessions indicate the two complications that they are trying to work out. Subsequently, for Shoba and Shukumar, the exchange of confessions is a means not only to work out their splintered selves but also to acknowledge their individuality, their idiosyncrasies as Indians, non-Americans. The couple takes advantage of the situation to communicate those aspects of the Indian culture that they could not endure and to express their discontent with the dominant culture which does its best to transform and to homogenize the other.

In fine, the blackout ends and it is time for a moment of truth. Even though their Indian-ness and matrimonial bond are quite a compelling rationale to keep them together, Shoba finds the courage to walk out of the marriage which represents the need of the diaspora to cling onto those who share their marginality, liminality, and the never-ending state of inbetween-ness. Shukumar, although curious about his inherited identity, prefers to "keep the lights off." Shoba, however, says, "I want you to see my face when I tell you this" (Lahiri, 1999 , p. 21). For Shoba, similar to any other displaced person yet to a more or less extent, "it is the construction of identity that constitutes freedom, because human beings are what they make of themselves, even if they are subjects of repressive discourses" (Ashcroft and Ahluwalia, 2001, p. 112). Fanon states, "It is through the effort to recapture the self and to scrutinize the self, it is through the lasting tension of their freedom that men will be able to create the ideal conditions of existence for a human world" (as cited in Ashcroft and Ahluwalia, 2001, p. 112). Eventually, the resistance displayed by Shoba against arranged marriages and subservience to patriarchal standards of India that has defined her womanhood is not a transgressive behavior or an act of betrayal but the assertion of her individuality and identity.

\section{Partition}

The other story in the collection, "When Mr. Pirzada Came to Dine," is founded upon the story of a Hindu Indian Bengali family's constant visitor, Mr. Pirzada. He is an Indian Pakistani who suddenly becomes a Bangladeshi, no longer an Indian, due to the ongoing 1971 Pakistan war, or Bangladesh independence war, that results in its Partition. His complexities of identity and belonging become negotiations and hazards of nationality and citizenship. He has been separated from his family for years and painfully yearns to be reunited with them. Lilia, the ten-year-old Indian American narrator, is caught between the traditions of her parents and American culture and tries, while being suppressed by the host community, to make sense of the profound contradictions of displacement, pains of separation, and relationships of guest communities. She says,

The supermarket did not carry mustard oil, doctors did not make house calls, neighbors never dropped by without an invitation, and of these things, every so often, my parents complained. In search of compatriots, they used to trail their fingers, at the start of each new semester, through the columns of the university directory, circling surnames familiar to their part of the world. It was in this manner that they discovered Mr. Pirzada, and phoned him, and invited him to our home. (Lahiri, 1999, p. 24)

After a lengthy discussion about the history of Partition, which Lilia clearly does not comprehend, this is how she presents her mother,

Lilia has plenty to learn at school,' my mother said. 'We live here now, she was born here.' She seemed genuinely proud of the fact, as if it were a reflection of my character. In her estimation, I knew, I was assured a safe life, an easy life, a fine education, every opportunity. I would never have to eat rationed food, or obey curfews, or watch riots from my rooftop, or hide neighbors in water tanks to prevent them from being shot, as she and my father had. 'Imagine having to place her in a decent school. Imagine her having to read during power failures by the light of kerosene lamps. Imagine the pressures, the tutors, the constant exams ... How can you possibly expect her to know about Partition'? (Lahiri, 1999, pp. 26- 27)

Her father, on the other hand, expects her to try to learn about the history of the land that she was not born into, and 
to listen to the national news. He presumes that the American educational system is to familiarize the diaspora children with their heritage. Srikanth (2003) argues that there is a "cynical but not invalid" assumption which deems the desire toward homeland destructive to the "already compromised position of Asian Americans as American citizens," and widens "divisions among Americans of color by reifying difference, and that it has reinforced the foreignness of Asians, regardless of their having been born in the United States" (p. 96). Then the educational system comes in to play its part. As Srikanth (2003) explains, ideally "The task for educators, then, is not to bemoan the phenomena but to teach students to engage analytically with the trend toward diaspora and transnational issues . . . to direct students to understand the complex interaction between local and transnational concerns" (p. 96). However, the educational system of the host community is not designed in a way so that it meets this expectation.

According to Ashcroft and Ahluwalia (2001), postcolonial theory is profoundly oriented towards "the nature and consequences of colonial education and the links between Western knowledge and colonial power" in conjunction with "the impact of imperial languages . . ., the effects of European 'master-discourses' such as history and philosophy" (p. 15). Furthermore, colonial powers tend to maintain homogeneity of their communities despite what is actually being advertised. Goldberg (2005) draws on the expressions used frequently by the multiculturalization programs such as "managing diversity," "ordering difference," and "unifying in difference," to reveal the controlling nature of "what one would have thought to be creative and energizing (diversity, difference)" (pp. 81-82). Therefore, the educational system, similar to any other institution in power, "homogenizes the heterogeneous, fixes the flux and flow, orders the dis-orderly" (Goldberg, 2005, p. 82), and hybridity and the resistance associated with it is silenced. Samuel P. Huntington (1993) similarly believes that "The clash of civilizations will dominate global politics. The fault lines between civilizations will be the battle lines of the future" (p. 22). Jenny Sharp (2005) claimed that the mid-1960s Multicultural Education Reform in the United States was to reflect the rising presence of Third World immigrants and compensate for the "under-representation of racial minorities" (p. 112). Conversely, although "justice, democracy, and equal opportunity" are engrained in most school students in the "educational apparatus" of the US, its "partiality" can be easily observed (Henry Shwartz, 2005, p. 9). Lahiri's character, Mrs. Kenyon, the school teacher, represents the educational system of the US. She catches Lilia reading a book about Pakistan; she takes the book as if it were a "hair" on Lilia's dress and demands her not to waste time consulting books that were not related to the curricular activities. This is what she observes at school the day after Lilia's family and Mr. Pirzada watch the war in Pakistan and India on television:

No one at school talked about the war followed so faithfully in my living room. We continued to study the American Revolution, and learned about the injustices of taxation without representation, and memorized passages from the Declaration of Independence. (p. 32)
Although over the course of the story no one treats Lilia like an outsider, she keenly observes and realizes that the world she now belongs to is not concerned with the world that she originally belongs to. She realizes that she does not belong. Lilia, at the end of the story, when Mr. Prizada returns and reunites with his family, says,

[It] was only then that I felt Mr. Pirzada's absence. It was only then, raising my water glass in his name, that I knew what it meant to miss someone who was so many miles and hours away, just as he had missed his wife and daughters for so many months. He had no reason to return to us. (p. 42)

In an interview, Lahiri, having Lilia's life in common, states that she constantly has to explain to her readers that she is not Indian, yet her name, her skin color and the design of her books makes people assume that she is Indian, that she has certain characteristics. Lahiri (1999) believes that her readers think that she is "Indian in the way that they want to think of [her] as Indian, having been born and brought up there, and that [she is] a foreigner in this country" (p. 74). To conclude, this is how the journey of a second-generation migrant girl for her identity begins; she becomes an Odyssey who endeavors to tear down the foreigner image and construct that of her own for her own while knowing that in the eye of the host she will always be the Other.

\section{Cupid's Academy}

In "Sexy," Lahiri explores another aspect of diaspora. Miranda, a young American girl, has an affair with a married Indian man named Dev. But the story begins by introducing a parallel story to that of Miranda's, an Indian man leaving his wife and child for another woman (an English woman) whom he met on a plane journey from USA to UK. Juxtaposition of the two stories reveals Lahiri's intention to portray that the two cultures always influence one another. Bahareh Bahmanpour (2010) stresses that "As threatening as the confrontation between the native Self and the immigrant Other can be, there is always an appeal and mutual attraction in between" (p. 49). She explains that the threat and charm is explicitly materialized in the sexual appeal between Miranda, the American female protagonist, and Dev, the Indian male protagonist of the story (p. 49). Regardless of how the romance ends, the marks left on the consciousness of these characters corresponds to the existence of ethnic and idiosyncratic characteristics.

As concerns the reciprocal relationship and influence of the host and the guest community, Edward Said believes that "what is critical in this writing back is the breaking down of barriers that exist between different cultures" (as cited in Ashcroft and Ahluwalia, 2001, p. 109). Said maintains that "the voyage in" is an influential force that can transform the colonial society and culture into making way for the "suppressed or forgotten" subaltern to blend in and be recognized. Nevertheless, the process will always be painful, and there will always be resistance regardless of what the other must write back because the Self will always try to maintain domination. According to Said, the resistance caused by the cultural inertia of the imperialist, which aims 
at "restoration of community," results in the resilience of the divide between the self and other; however, "human liberation" becomes possible only when all the efforts are culminated to unite the self and the other (as cited in Ashcroft and Ahluwalia, 2001, p. 109). Writing back is the means that targets elimination of marginalization, liminality, and alienation of the other and the assimilation of the rich cultures as well as valuable human experience of the subaltern by the self and other.

Miranda tries to adopt Bengali culture, as she tries to learn Bengali language, to eat Indian food, to watch Indian movies, and to transcribe the Indian part of her name. “As portrayed in Miranda's fascination with Indian culture upon meeting Dev, native Self covertly takes an interest in knowing and locating the immigrant Other" (Bahmanpour, 2010, p. 49). When she meets Dev, she thinks that Bengali is a religion and she knows very little about Indian culture, history, and geography, but she "is soon intrigued by the thrill of exploring the Other-a sense of thrill which encourages her to "try to assimilate Indian culture" (Bahmanpour, 2010, p. 49). Subsequently, "this Self/Other confrontation then posits Miranda's identity on the verge of an open-ness to the Other" (Bahmanpour, 2010, p. 49). Goethe believes that nations must cherish mingling of cultures and "mutual conflicts" because nations

could not return to their settled and independent life again without noticing that they had learned many foreign ideas and ways, which they had unconsciously adopted, and come to feel here and there previously unrecognized spiritual and intellectual needs. (as cited in Bhahba, 2004, p. 26)

Similarly, Miranda and Dev both view the other as exotic experience, that which facilitates further human communication resulting in peaceful non-dominance-seeking multiculturalization of societies.

While the exotic nature of the new land has engrossed Dev, his favorite place in the city is the "Mapparium" where he can spot India on a map. One day, he takes Miranda there,

One Saturday, following an afternoon concert at Symphony Hall, he showed her his favorite place in the city, the Mapparium at the Christian Science center, where they stood inside a room made of glowing stained-glass panels, which was shaped like the inside of a globe, but looked like the outside of one. In the middle of the room was a transparent bridge, so that they felt as if they were standing in the center of the world. Dev pointed to India, which was red, and far more detailed than the map in The Economist. He explained that many of the countries, like Siam and Italian Somaliland, no longer existed in the same way; the names had changed by now. (Lahiri, 1999, p. 90)

Miranda then finds London on the map. However, to her, London is no longer the capital of England; it is rather the place where an Indian man has fallen in love with an English woman. Now, however temporarily, the world becomes a smaller and more amicable place where people can meet and connect.

Later in the story, Miranda remembers her childhood and the Indian community in her neighborhood with their dissim- ilarities and their alienation. She realizes that the children of the Indian family in their neighborhood were mocked by the Americans, that she felt threatened by the exotic nature of the Indian culture. She remembers that she was "too frightened even to walk on the same side of the street as the Dixits' house ... . For a while she even held her breath until she reached the next lawn, just as she did when the school bus passed a cemetery." But now, not only does she not hold her breath but she tries to cease every opportunity to smell Dev. "It shamed her now. Now, when she and Dev made love, Miranda closed her eyes and saw deserts and elephants, and marble pavilions floating on lakes beneath a full moon" (Lahiri, 1999, p. 96).

Lahiri (1999) beautifully captures Miranda's various ranges of emotions: joy, doubt, and grief. Eventually, Miranda realizes the destructive nature of her affair. Rohin, the boy who was abandoned by his father in the parallel story, triggers the domino effect that finally leads to their separation. He describes Miranda as sexy, as Dev has done earlier in the story, and he defines the word sexy as "loving someone you don't know" (p. 107). Then, she remembers:

In the Mapparium that day, all the countries had seemed close enough to touch, and Dev's voice had bounced wildly off the glass. From across the bridge, thirty feet away, his words had reached her ears, so near and full of warmth that they'd drifted for days under her skin. (p. 108)

It is the thought of clichés such as broken marriages, clash of cultures, and the damaging ramifications of inter-racial connections that prompts the end of the relationship. According to Bahmanpour (2010), "This call for a healthy Self/Other relationship, however, fails for the very reason that the response of the immigrant Other is not as open as the native Self' (p. 49). Additionally, Spivak believes that a true Self/Other relationship "engages the Other in non-essential, non-crisis terms" (as cited in Bahmanpour, 2010, p. 49). Miranda and Dev, as the representatives of the native Self and the Other, are both victims of stereotypes which are the reason why they are not able to fashion, in Landry's (1996) words, "the ethical stance of making discursive room for the Other to exist" (p. 6). However, what this nipped-in-the-bud romance has brought about is the awareness of the fact that the world comprises of a vast variety of ethnicities that can only be acknowledged through human experience and true contact.

\section{Twinkle, Twinkle, Little Star}

The theme of ambivalent identity is discernable in Lahiri's "This Blessed House," too. It is the story of a young Asian couple, Sanjeev and Twinkle, who have just started their married life in the US. They come from different cultural backgrounds with different experiences. The story deals with a relatively early period of the married life when the partners are quite emotionally attached to each other. The couple keeps encountering flashy Christian things left behind by their home's former owners. Twinkle is excited about these discoveries and starts calling the house 'a blessed house,' whereas Sanjeev is not happy with it. 
Twinkle, the female protagonist of the story, is representative of the second-generation female diaspora who, in Bahmanpour's (2010) terms, "being submerged by the culture of the Other for rather a long time, have fashioned such hybrid diasporic identities which let them survive and succeed even far above their male counterparts" (p. 47). Bahmanpour (2010) believes that the significance of the character is in her non-traumatic experience of dislocation (p. 47). Twinkle is twenty-seven years old and has recently been abandoned by an American lover who has aspired but failed to become an actor. Instead of cooking fresh meals like Indian women, she buys pre-roasted chicken and other ready-made food. She does not seem to be quite enthusiastic about household chores; nor could she operate the blender in the kitchen. Lahiri, through Twinkle, explores both the complications of an arranged marriage and the adjustments that must be made to accommodate a couple's different personalities, one on the verge of transforming into an American, the other trying desperately to hold on to his Indian heritage.

Sanjeev, on the other hand, represents those male migrants who resist dissolving in the dominant culture of the host society, in his case, by rejecting the religious beliefs that appear quite appealing to his wife. Sanjeev, is an MIT graduate, who has benefitted from the facilities and opportunities that America has furnished him with. He is going to work as a vice president of a company, have his secretary, and have people work under him. He enjoys the Western luxury, yet, he, unlike Twinkle, is at a different stage of transformative identity; he is in denial. As explained by Bhabha (2004), "the disavowal of the Other [or the Self] always exacerbates the edge of identification ... . for denial is always a retroactive process; a half acknowledgement of that otherness has left its traumatic mark" (p. 88). He takes immense pleasure in eating Indian food after long hours of work in college, listens to Indian music, and feels irritated by Twinkle wearing high heels because that makes him look shorter which represents his traditional Indian patriarchal views. He constantly demands that twinkle acknowledge their Hindu heritage by stating the obvious that "we are not Christian" (Lahiri, 1999, p. 137). In order to remove these symbols from the house, Sanjeev disputes with Twinkle.

The aggression and intolerance exhibited by Sanjeev is triggered by his insistence on preservation of Indian culture that seems to define his existence. Debarati Bandyopadhyay (2009) draws on Edward Said's concept of culture to elaborate on the relationship between one's self and culture;

Culture is a concept that includes a refining and elevating element, each society's reservoir of the best that has been known and thought, as Matthew Arnold put it in the 1860s. Arnold believed that culture palliates, if it does not altogether neutralize, the ravages of a modern, aggressive, mercantile and brutalizing urban experience ... . . In time culture comes to be associated, often aggressively, with the nation or the state; this differentiates 'us' from 'them,' almost always with some degree of xenophobia. Culture in this sense is a source of identity, and a rather combative one at that. (p. 98)
Bandyopadhyay (2009) argues that Lahiri's characters in this story are in-between two very different concepts of culture each facilitating the identity formation in its own way: one is "India with her concept of 'unity in diversity' and the US as the melting pot of cultures and races" (p.98). Additionally, "multiculturalism" proposes existence and concurrence of multiple cultures rather than "homogenization and conformity" or denigration, marginalization, and alienation of a particular culture of minority or majority by another, because this is how "the fragile balance of" a multicultural society is sustained (p. 98). Hence, it is a preference to welcome multiplicity and to embrace the conflicting aspects of the blended culture. It is this dynamic positive hybridity present in Twinkle that makes her survival definite and gives her superiority and charm over other female characters whose confrontation with the other either involves them in cycles of escape or at most in a total otherness. Yet, for Twinkle, it goes beyond acceptance of multiplicity of host/guest cultures or pretentious behavior indicative of transformation of identity. As Chetty avers, Twinkle does not mimic American-ness because the concealed shame, associated with imitation, felt toward one's own cultural heritage is absent; "In fact, not only has she accepted the culture of the Other, ... but also, positively negotiates her identity as an American of Indian descent" (as cited in Bahmanpour, 2010, p. 47). Although the quarrels never lead to their separation, the ending of the story has promises of upcoming complications. Nevertheless, Twinkle's auspicious example is indicative of the fact that there is still time and hope of survival for those non-dynamic characters like Sanjeev and Mrs. Sen, the characters of another short story by the same title, to pass into the hybrid space.

In addition to what went before, those similar to Twinkle, who are in search of identity, need to overcome the resistance of their fellow diaspora as well as the host community, which seems to be a never-ending task. In the same vein, Lihiri (1999) remarks,

In fact, it is still very hard to think of myself as an American. For immigrants the challenges of exile, the loneliness, the constant sense of alienation, the knowledge of and longing for a lost world, are more explicit and distressing than for their immigrants, those with strong ties to their country of origin, is that they feel neither one thing nor the other. The feeling that there was no single place to which I fully belonged bothered me growing up. It bothers me less now. (p. 81)

Bhabha (2004) labels what Twinkle underwent "the moment of interrogation" in which either the colonial power or the fellow diaspora interrogates the subject because they do not resemble those either in the colonial culture or in that of the immigrants; in such moments "the demand for identification becomes primarily a response to other question of signification and desire, culture and politics" (p. 71). The moment an immigrant makes the transformation into the native Self, they instantaneously become the Other to their fellow immigrants. Therefore, this postcolonial aporia (to borrow from Jacques Derrida) of identity becomes the byproduct of a policy that holds: you are both with us and against us. 


\section{CONCLUSION}

To conclude, in the discussed Lahiri's stories, namely, "A Temporary Matter," "When Mr. Pirzada Came to Dine," "Sexy," and "This Blessed House", the first-generation migrants with stronger ties to their homeland and the associated cultural values always attempt to compensate for their loss through reincarnating India in their children (the second-generation migrants). Aggravating the condition, the unwavering tendency of the indigenous to sieve out the elements of heterogeneity and multiculturalism aimed at maintaining homogeneity has given rise to an educational institution that, while taking pride in its multiculturalist structure, takes for granted the (second-generation) children of diaspora and hinders their identity formation and blending in. Knowing the very fact that one is of Indian descent always affects the mannerisms of the Other and the attitude of the native Self. Therefore, all these result in identity ambivalence and reactions, including acceptance, rejection, acculturation, camouflage, and escape. To close, considering the diversity of individuals' personalities, it is utterly impossible to capture all forms of sufferings associated with displacement; nevertheless, what matters is to voice the concerns of the hybrid diaspora through migrant literature (writing back), acknowledge the constant changing and becoming of the diaspora's identity, and assimilate the nourishing essence of peaceful human experiences in an atmosphere where coexistence of cultures is facilitated.

\section{REFERENCES}

Anwer, Megha. (2017). After melancholia: A reappraisal of second-generation diasporic subjectivity in the work of Jhumpa Lahiri. Rev. Journal of Postcolonial Writing. Retrieved 21 April 2017. http://www.tandfonline. com/doi/abs/10.1080/17449855.2017.1283727?journalCode=rjpw20.

Ashcroft, Bill, and Pal Ahluwalia. (2001). Edward Said. London: Routledge.

Bahmanpour, Bahareh. (2010). Female Subjects and Negotiating Identities in Jhumpa Lahiri's Interpreter of Maladies. Studies in Literature and Language, 1(6), 43-51. Retrieved 21 April 2017. www.cscanada.net/index.php/ sll/article/view/j.sll.1923156320100106.006.

Bandyopadhyay, Debarati. (2009). Negotiating Borders of Culture: Jhumpa Lahiri's Fiction. Journal of Literature, Culture and Media Studies, (1), 97-98. Retrieved 21 April 2017. www.inflibnet.ac.in/ojs/index.php/JLCMS/ article/viewFile/9/8.

Bhabha, Homi K. (2004). The Location of Culture. New York: Routledge.

Brada-Williams, Noelle. (2004). Reading Jhumpa Lahiri’s Interpreter of Maladies as a Short Story Cycle. MELUS. 29(3/4),451-464.Retrieved21April2017.https://academic.oup.com/melus/article-abstract/29/3-4/451/1080624/ Reading-Jhumpa-Lahiri-s-Interpreter-of-Maladies-as?redirectedFrom=fulltext.

Goldberg, David Theo. (2005). Heterogeneity and Hybridity: Colonial Legacy, Postcolonial Heresy. A companion to postcolonial studies. Edited by Henry Schwarz and Sangeeta Ray. $2^{\text {nd }}$ ed. Australia: Blackwell.

Heinze, Ruediger. (2007). A Diasporic Overcoat? Journal of Postcolonial Writing, 43(2), 191-202. Retrieved 2 January 2017. http://www.tandfonline.com/doi/ abs/10.1080/17449850701430598.

Huntington, Samuel P. (1993). The Clash of Civilizations. Foreign Affairs, 72(3): 22-49. Retrieved 21 April 2017. DOI: $10.2307 / 20045621$.

Katrak, Ketu H. (2002). The Aesthetics of Dislocation: Writing the Hybrid Lives of the South Asian Americans. The Women's Review of Books. 19(5), 5-6. Old City Publishing, Inc. Retrieved 16 April 2016. http://www.jstor.org/ stable/4023785.

Lahiri, Jhumpa. (1999). Interpreter of Maladies. New York: Houghton Mifflin.

Landry, D. and G. Maclean. (1996). The Spivak Reader. New York and London: Routledge.

Leyda, Julia. (2011). An Interview with Jhumpa Lahiri. Contemporary Women's Writing, 5(1), 66-83. Retrieved 2 January 2017. https://academic.oup. com/cww/article-abstract/5/1/66/327848/An-Interview-with-Jhumpa-Lahiri?redirectedFrom=fulltext.

Lutzoni, Silvia. (2017). Jhumpa Lahiri and the Grammar of a Multi-Layered Identity. Journal of Intercultural Studies, 38(1), 108-118. Retrieved 2 January 2017. http://www.tandfonline.com/doi/ $\mathrm{abs} / 10.1080 / 07256868.2016 .1269062$ ?journalCode $=\mathrm{c}-$ jis20.

Madsen, Deborah L. (2003). Beyond the Borders, American Literature and Post-colonial Theory. London: Pluto Press.

Macwan, Hiral. (2014). Struggle for Identity and Diaspora in Jhumpa Lahiri's The Namesake. International Journal of Humanities and Social Science Invention, 3(12), 45-49. Retrieved 2 January 2017. www.ijhssi.org/papers/v3(12)/Version-1/G031201045049.pdf.

Noor, Ronny. (2000). Jhumpa Lahiri. Interpreter of Maladies. Rev. of Interpreter of Maladies, World Literature Today, 74(2), 365-366. Retrieved 2 January 2017. http:// www.jstor.org/stable/40155634? origin=crossref\&se$\mathrm{q}=1 \#$ fndtn-page_scan_tab_contents.

Schwarz, Henry, and Sangeeta Ray. (2005). A companion to postcolonial studies. Malden: Blackwell.

Sharp, Jenny. (2005). Postcolonial Studies in the House of US Multiculturalism. A companion to postcolonial studies. Edited by Henry Schwarz and Sangeeta Ray. Malden: Blackwell.

Shukla, Shilpa and Niroj Banerji. (2012). The theme of 'alienation' and 'assimilation' in the novels of Bharati Mukherjee and Jhumpa Lahiri: A socio - literary perspective. International Journal of English and Literature, 5(1), 19-22. 4 January 2017. http://academicjournals.org/journal/IJEL/article-abstract/3B50DFE42714.

Srikanth, Rajini. (2003). Unsettling Asian American Literature: When More than America is in the Heart. Beyond the Borders, American Literature and Post-Colonial Theory. Edited by Deborah L. Madsen. London: Pluto Press. 